研究

$\mathrm{TiAl}_{3}$ の放電焼結による固化成形

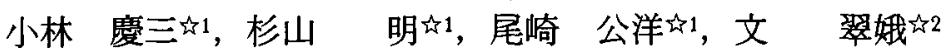 \\ 中1 名古屋工業技術研究所, 宁462 名古屋市北区平手町1-1. \\ 化 2 北京航空航天大学, 100083 中国北京学院路 37
}

\title{
Consolidation of Titanium Tri-aluminide using by Spark Plasma Sintering
}

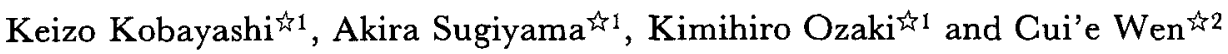 \\ 41 National Industrial Research Institute of Nagoya, AIST, MITI, 1-1 Hirate-cho Kita-ku, Nagoya 462. \\ \{2 Beijing University of Aeronautics and Astronautics, 37 Xueyuan Road, Beijing, 10083, P.R. China.
}

Received February 17, 1997

\section{SYNOPSIS}

Ti-5mass\%Al, Ti-10mass\%Al, Ti-32mass\%Al and Ti-64mass\%Al were synthesized by mechanical alloying (MA) of Ti powder and Al powder using a planetary ball milling for $360 \mathrm{ks}$ in $66 \mathrm{kPa}$ argon gas atmosphere. Ti64 mass\% Al powder milled for $360 \mathrm{ks}$ was $\mathrm{Al}$ solid solution. Non stoichiometric Ti-Al powder milled for $360 \mathrm{ks}$ became amorphous state with an increase of $\mathrm{Al}$ content in the MA powder.

The mixture of MA powder and $\mathrm{Al}$ powder, which contained 64 mass $\% \mathrm{Al}$, was consolidated by spark plasma sintering(SPS). The starting temperature for shrinkage in SPS process was decreased by the addition of Al powder into MA powder. In the mixture of $\mathrm{Ti}-5$ mass\% $\mathrm{Al}$ MA powder and Al powder, the consolidated $\mathrm{TiAl}_{3}$ was obtained by SPS at $1073 \mathrm{~K}$ for $0.3 \mathrm{ks}$. This sintered body had a homogeneous fine microstructure.

KEY WORDS

$\mathrm{TiAl}_{3}$, mechanical alloying, spark plasma sintering, forming, non stoichiometric powder

\section{1 緒言}

$\mathrm{Ti}-\mathrm{Al}$ 系金属間化合物は軽量の高温構造用材料として の応用が期待されている ${ }^{1,2)}$. なかでも， $\mathrm{TiAl}_{3}$ 金属閒化 合物は最も軽量で耐酸化性に優れる合金3)である.し かし, $\mathrm{TiAl}_{3}$ は溶融状態での高反応性のため, 鋳造での 成形が難しい. また， $\mathrm{TiAl}_{3}$ は常温における延性に乏し く，機械加工や塑性加工による成形も困難である。一 方, 合金を構成する素粉末を機械的に混合・粉砕する メカニカルアロイング (MA) 法では種々の組成の非平 衡粉末を作製することができる.これまでにアルミナ イド金属間化合物の成形方法として，化学量論組成よ り Al量の少ない合金粉末をMA法で作製し, Al粉末を 添加して成形する方法4-6)について報告してきた。この 方法では添加したAlを溶解させることにより, Al液相
の存在下での成形が可能であり，その後の加熱による 燃焼合成反応を利用した金属間化合物相の合成が可能 である.さらに, 成形時の液相量はMA 粉末の組成に よって調整でき, 半溶融加工ク と同じメカニズムでの 成形が可能である.また，有機バインダーを用いない 成形方法であるため, 焼結体の気孔量の減少も期待さ れる.そこで, MA 法により Ti-5mass\%Al, Ti10mass\%Al, Ti-32mass\%Al および Ti-64mass\%Al (TiAl ${ }_{3}$ ) 組成の粉末を合成し，この粉末に Al 粉末を添加して $\mathrm{TiAl}_{3}$ 組成としてその固化成形性を調へたた，また，Ti5mass\%Al組成の MA粉末に Al粉末を添加して TiAl 3 組 成にし，943Kでの押し出し成形を試みた.

\section{2 試料調整およひ実験方法}

「粉体拉よび粉末治金」第44巻第 6 号 


\section{$2.1 \mathrm{Ti}-\mathrm{Al}$ 合金の MA}

Ti-Al 合金の MA は, $\mathrm{Al}$ 粉末 (99.5mass\%Al) および Ti粉末 (99.0mass\% Ti) を出発原料として行った。 それ ぞれの粉末をTi-5mass\%Al, Ti-10mass\%Al, Ti32mass\%Al, Ti-64mass\%Al 組成になるように科量し, 遊星型ボールミル (伊藤製作所製) を用いて最長 $720 \mathrm{ks}$ 間の MA 処理を行った. MAの雰囲気は66kPaの减圧 アルゴン雾囲気とし, 容器 $(500 \mathrm{ml})$ およびボール $(10 \mathrm{~mm} \phi)$ にはクロム鎆製のものを用いた：容器は 170r.p.m.で回転させた.なお, ボールと粉末の配合は 重量比で 0.1 とした. 所定の時間のMA処理を行い, 全 粉末を回収した，得られた粉末はその構成相を同定す るためX線回折を行った。

\section{$2.2 \mathrm{MA}$ 粉末の固化成形}

得られたそれぞれの MA 粉末に A1 粉末を乳鉢混合 し,Ti-64mass\%Al組成にした. 固化成形方法は種々の 方法が考えられるが, 低温での成形が可能とされるパ ルス通電焼結 ${ }^{8}$ を採用した.この方法では難焼結性と されるAl粉末の焼結が容易に行われるため, 本成形プ ロセスには適しているものと考えられる.この混合粉 末を黒鉛製のダイ (内径 $15 \mathrm{~mm}$ ) に入れてパルス通電焼 結 (住友石炭鉱業製 SPS-510L : 以下 SPS と記す) によ り固化成形した。 なお，一般にはこの固化方法を放電 プラズマ焼結と呼んでいるが，我々の研究グループで は焼結時にプラズマが末だ観測されていない9ので本 報告ではパルス通電焼結と呼ぶ. 焼結温度は $1073 \mathrm{~K}$ と して 0.3ks 間の保持を行った。焼結時の成形圧力は $33 \mathrm{MPa}$ とし, 昇温開始から試料取り出しまで連続的に 加圧した. 昇温に伴う試料高さの変化をモニタリング し，その焼結特性を評価した。 また，押し出し成形用 の試料 (成形体) も本装直にて 773K で 0.3ks 間保持す ることにより作製した. 得られた焼結体および成形体 はX線回折によりその構成相の同定を行った。また， 焼結体については光学顕微鏡により組織観察を行った。

\section{3 実験結果および考察}

3.1 MA 合成した $\mathrm{TiAl}_{3}$ 粉末の固化成形

Ti-64mass\%Al組成のMA粉末のミリング時間に伴う 構成相の変化をFig.1に示す. 180ks 間の MA 処理では, 出発原料である $\mathrm{Ti}$ およ゙ $\mathrm{Al}$ のやや幅広い結晶ピーク が観察される、しかし，360ksの MA処理によってそれ らのピークはなくなっている. $\mathrm{TiAl}_{3}$ の MAはこれまで 多くの研究者によって行われており，4面体構造の粉 末 ${ }^{10)}$ P.c.c. 椿造の Al 固溶体 ${ }^{11)}, \mathrm{L1}_{2}$ 型の規則構造 ${ }^{12}$

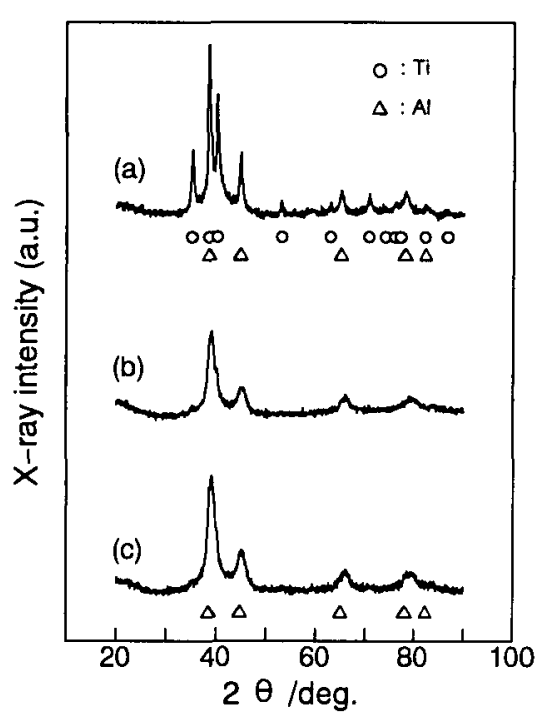

Fig. $1 \mathrm{X}$-ray diffraction patterns of Ti-64mass\%Al milled for (a) $180 \mathrm{ks}$,(b) $360 \mathrm{ks}$ and (c) $720 \mathrm{ks}$.

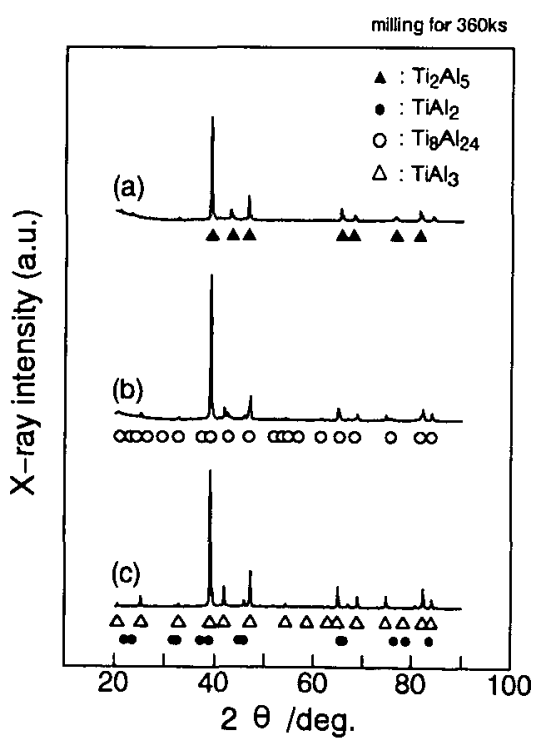

Fig. 2 X-ray diffraction patterns of Ti-64mass\%Al milling for $360 \mathrm{ks}$ sintered at (a)873K, (b) $1073 \mathrm{~K}$ and (c)1273K.

などが報告されている。本実験条件においては 360ks 間のMAにより Alの固溶体が得られた. $720 \mathrm{ks}$ 間のMA 粉末の X線回折パターンと $360 \mathrm{ks}$ 間の MA 粉末の X 線 回折パターンがほとんど変化しないことから，本実験 条件における安定相はこのAl固溶体と考えられる.こ 
のAI固溶体の形成前にアモルファス状態の粉末が得ら れるとの報告11) もあるが，本実験ではアモルファス相 の確認はできなかった．おそらく投入されたエネル ギーの違いによって,アモルファス相が存在するミリ ング時間が変化するものと推察される. 本実験条件で は $180 \mathrm{ks}$ から 360ks の間のわずかな時間のみアモル ファス相が存在するものと考えられる.構成相の大き な変化のなかった 360ks 間ミリングした粉末をパルス 通電により種々の温度で焼結した. 得られた焼結体の $\mathrm{X}$ 線回折パターンを Fig.2に示す. $873 \mathrm{~K} て ゙ 0.3 \mathrm{ks}$ 間保持 した焼結体では結晶粒の粗大化が進行しておらず，他 の温度の焼結体よりそのX線回折ピークが幅広くなっ ている.また，その回折ピーク位置は，準安定相であ る $\mathrm{Ti}_{2} \mathrm{Al}_{5}$ 相とほぼ一致している.また, 873Kでの焼結 体はかなり多孔質であった。ささらに焼結温度を上げる と緻密化が進行した. その回折ピーク位置は焼結温度 が高くなるほど, $\mathrm{TiAl}_{3}$ 相へと変化する. しかし， $1273 \mathrm{~K}$ で 0.3ks 間保持しても，その焼結体は完全な $\mathrm{TiAl}_{3}$ 単相とはならず, $\mathrm{TiAl}_{2}$ 相を含む X 線回折パター ンとなった. MA粉末の組成は $\mathrm{TiAl}_{3}$ の化学量論組成よ り若干 $\mathrm{Al}$ 量が多くなっているが，Tiに富む $\mathrm{TiAl}_{2}$ 相が 共存する結果となった.これは焼結の保持時閒が短く， 平衡相に達していないためと考えられる．また，焼結 温度による構成相の違いは，MAによって形成された

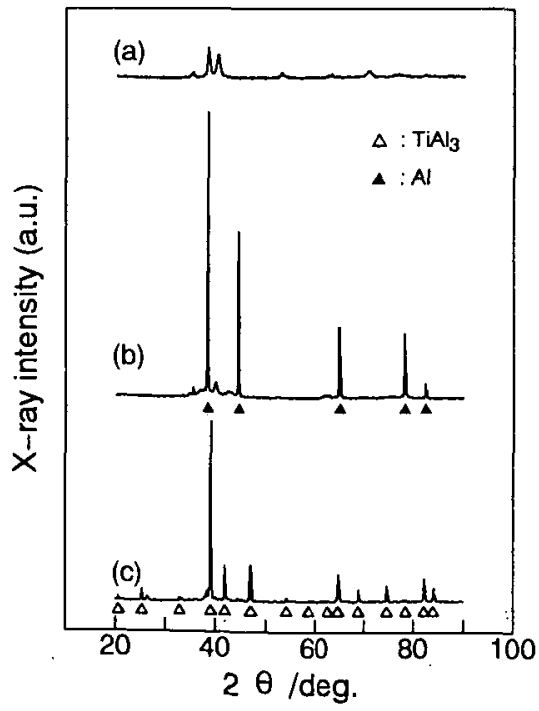

Fig.3 X-ray diffraction patterns of (a)MA Ti-5mass\%Al powder and Ti-64mass\%Al mixture of MA Ti-5mass\%Al and $\mathrm{Al}$ sintered at (b)773K and (c) $1073 \mathrm{~K}$ by SPS.
$\mathrm{Al}$ 固溶体から Tiを核にして結晶が成長し; 焼結温度の 上年とともにAlに富んだ金属間化合物が形成されたた めと推察される.なお, 本パルス通電焼結においては, 焼結温度を黒鉛型で測定しているため黒鉛型内部の試 料温度はその温度より $10 \%$ 程度高い温度と推察され る.

\section{$3.2 \mathrm{MA}$ 粉末と $\mathrm{Al}$ 粉末の混合体の固化成形}

Ti-5mass\%Al, Ti-10mass\%AlおよびTi-32mas\%Al粉末 を 360ks 間の MAにより合成し，この粉末に Al粉末を 乳鉢混合して Ti-64mass\%AI 組成の混合粉末を作製し

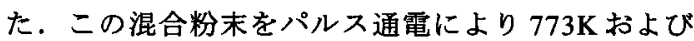
1073Kで 0.3ks 間保持することによって焼結した. MA により合成したTi-5mass\%A1粉末にA1粉末を添加して パルス通電焼結した場合の構成相の変化を Fig.3に示 す. MA 粉末は幅広いTi の結晶ピークを有している. この MA 粉末に $\mathrm{Al}$ 粉末を添加して $\mathrm{Al}$ の融点以下であ る 773Kにてパルス通電焼結すると, Al と MA 粉末の 複合材料となっている.MA粉末は773Kの熱が付加さ れたため，やや結晶性が強くなった．さらに，1073K で焼結すると，ほぼ $\mathrm{TiAl}_{3}$ 単相となっている. 1073Kま で昇温する際に33MPaの加圧を行っているにも関うら ず, 成形中の $\mathrm{Al}$ 液相の溶出は钼察されなかった.この ことから, Alの液相が生じた直後にMA粉末と $\mathrm{Al}$ との 反応が生じたものと推察される。

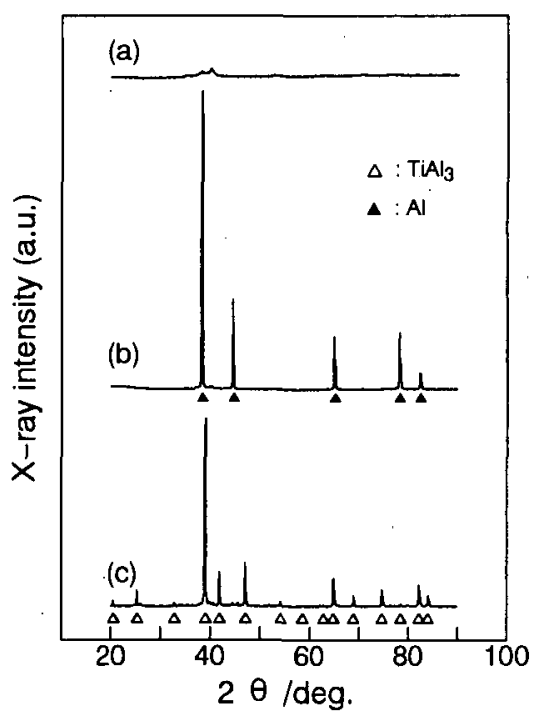

Fig.4 X-ray diffraction patterns of (a)MA Ti-10mass\%Al powder and Ti-64mass\% $\%$ l mixture of MA Ti-10mass\%Al and $\mathrm{Al}$ sintered at(b) $773 \mathrm{~K}$ and (c) $1073 \mathrm{~K}$ by SPS. 


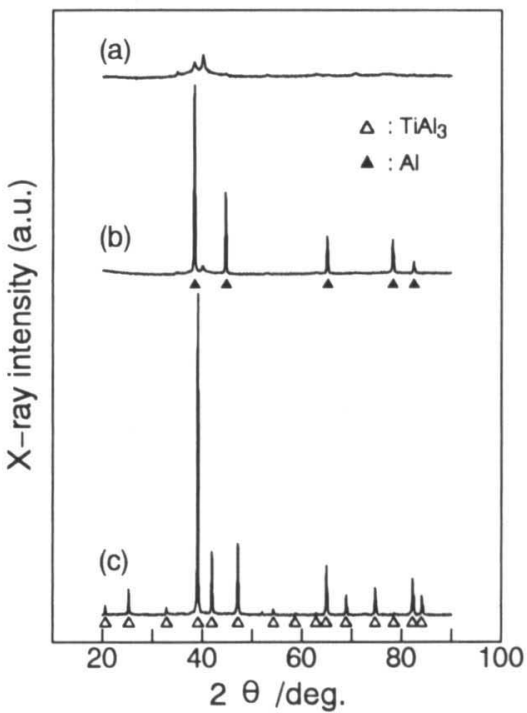

Fig.5 X-ray diffraction patterns of (a)MA Ti-32mass\%Al powder and $\mathrm{Ti}-64 \mathrm{mass} \% \mathrm{Al}$ mixture of MA Ti-32mass\%Al and $\mathrm{Al}$ sintered at (b) $773 \mathrm{~K}$ and (c) $1073 \mathrm{~K}$ by SPS.

MA粉末としてTi-10mass\%Al組成の粉末を用いた場 合の構成相の変化を Fig.4 に示す. Ti-10mass\%Al 組成 の MA 粉末は Ti-5mass\%Al 組成の MA 粉末に比べて, かなり非晶質化している. この粉末にA1粉末を添加し て773K でパルス通電焼結すると, 焼結体は Ti5mass\% Al の MA 粉末の場合と同じく $\mathrm{Al}$ と MA 粉末の 複合材料となっている.さらに, 1073K で焼結すると $\mathrm{TiAl}_{3}$ 相が合成されている. Ti-5mass\%Alの MA 粉末の 場合に比べ, $\mathrm{TiAl}_{3}$ 相以外の結晶ピークが減少してい る.これは MA 粉末がアモルファス化したため, $\mathrm{Al}$ と の反応性が高くなったものと考えられる.

Ti-32mass\%Al組成のMA粉末を用いた場合の構成相 の変化を Fig.5に示す. MA 粉末は幅の広いTiのピーク を有するX線回折パターンを示している.これは $\mathrm{Al}$ 量 が多くなったため, MAの効率が低下したものと考え られる. 実際, 得られた粉末はかなり凝集しており粗 くなっていた. これに $\mathrm{Al}$ 粉末を添加して 773K でパル ス通電焼結すると, $\mathrm{Al}$ と MA 粉末の複合材料となっ た. さらに, $1073 \mathrm{~K}$ でパルス通電焼結すると $\mathrm{TiAl}_{3}$ 相が 合成された.

MA粉末と A1粉末の混合粉末の $1073 \mathrm{~K}$ における焼結 体はいずれも $\mathrm{TiAl}_{3}$ 相で構成されていた.これは, MA 粉末と $\mathrm{Al}$ 液相との反応時に発生する熱によって $\mathrm{TiAl}_{3}$ の合成が促進されるため, Ti-64mass\%Al組成の MA 粉

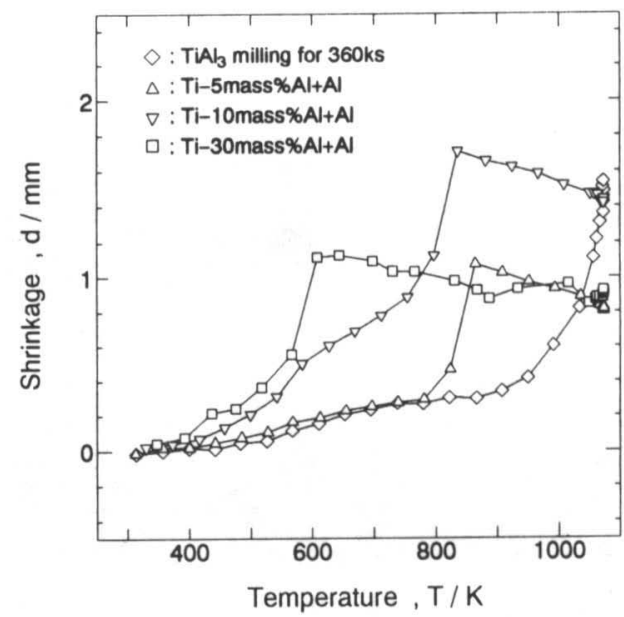

Fig.6 Shrinkage of Ti-64mass\%Al plotted against sintering temperature.

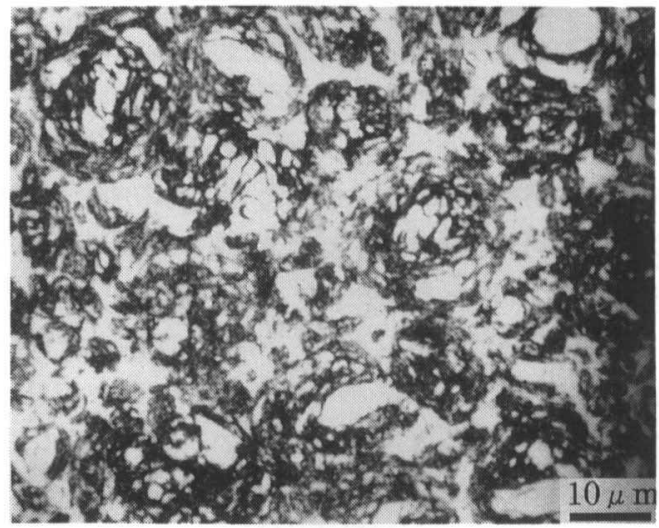

Fig.7 Microstructure of the SPS body of MA Ti-64mass\%Al sintered at $1073 \mathrm{~K}$ for $0.3 \mathrm{ks}$. MA Ti-64mass $\% \mathrm{Al}$ powder was prepared by $360 \mathrm{ks}$ milling in $66 \mathrm{kPa} \mathrm{Ar}$.

末の焼結体より $\mathrm{TiAl}_{3}$ 相の含有量が多くなっているも のと考えられる.

$\mathrm{MA}$ 粉末の組成が異なると, パルス通電焼結時の変 形特性にも差が生じてくる. 360ks間のMA処理を行っ た Ti-5mass\%Al, Ti-10mass\%AlおよびTi-32mass\%Al 組 成の粉末に Al 粉末を添加した混合粉末と $\mathrm{Ti}$ 64mass\%Al組成の MA粉末のパルス通電焼結における 収縮挙動を Fig.6に示す. 横軸は黒鉛型の温度であり, 縦軸は黒鉛治具の熱膨張量を含めた試料の収縮量を示 している.Ti-64mass\%A1組成の MA 粉末は 1000Kを越 えてから焼結が進行することがわかる.これに対して, 


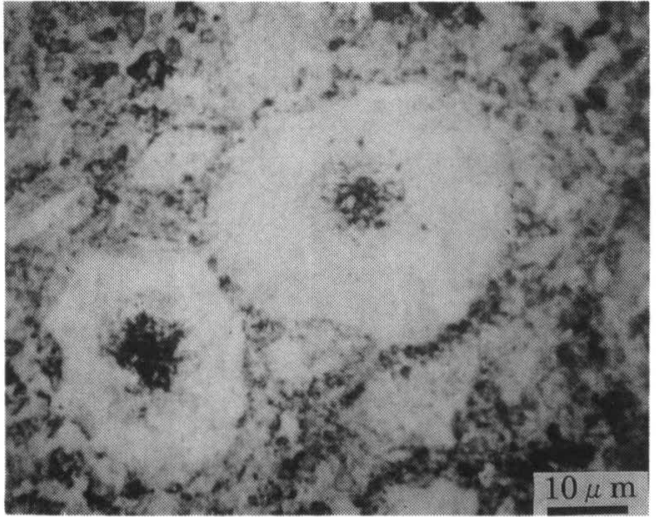

Fig. 8 Microstructure of the SPS body of MA Ti-5mass $\%$ Al and $\mathrm{Al}$ sintered at $1073 \mathrm{~K}$ for $0.3 \mathrm{ks}$. MA Ti-5mass $\% \mathrm{Al}$ powder was prepared by $360 \mathrm{ks}$ milling in $66 \mathrm{kPa} \mathrm{Ar}$.

非化学量論組成のMA粉末にAlを添加して作製した混 合粉末はより低温で焼結が進行している．特に，MA 粉末中の Alが多くなるほど, 低温から焼結が進行し始 める傾向が認められる.これは, MA粉末中の $\mathrm{Al}$ が増 加すると粉末が造粒されるため, 添加した $\mathrm{A} 1$ 粉末が MA粉末の間隙を充填しやすく $\mathrm{Al}$ と MA粉末との接合 が低温から生じるものと考えられる. Ti-64mass\%Al組 成の MA 粉末をパルス通電焼結を用いて，1073K で $0.3 \mathrm{ks}$ 間保持することによって得られた焼結体の光学顕 微鏡組織を Fig.7に示す. 組織は粗く, 不均一なものと なっている. また, 焼結体中には多くの気孔も観察さ れる. 一方, Ti-5mass\%Al 組成の MA粉末に $\mathrm{Al}$ 粉末を 添加して, 同じ条件で固化成形した焼結体の光学顕微 鏡組織を Fig.8 に示す. 組織にはあまりむらがなく, MA粉末の形骸と考えられる大きな粒子の中に小さな 気孔が観察される.これは, MA 粉末が $\mathrm{Al}$ と反応した 際の体積変化に伴う気孔であると推察される.なお, MA 粉末が微細な部分では均一な微細組織を呈してい る. 以上のことから, パルス通電焼結による MA 粉末 の固化成形においては, 化学量論組成より $\mathrm{Al}$ 量の少な い粉末を MA で合成し, $\mathrm{Al}$ 粉末を添加してから成形し た方が緻密で $\mathrm{TiAl}_{3}$ 単相の焼結体が得られやすいこと がわかった.

MA粉末にA1粉末を添加してパルス通電焼結により 固化成形すると $773 \mathrm{~K}$ の焼結温度でも, $\mathrm{Al}$ と MA 粉末 の緻密な複合材料を作製することができる.この成形 体を用いて半溶融成形装置》を用いて押し出し成形を
試みた. 添加した Alを液化するため $943 \mathrm{~K} て ゙ 0.3 \mathrm{ks}$ 間保 持し, $27 \mathrm{MPa}$ の加圧力にて押し出した. しかし, 押し 出し比が 1:10では押し出すことができなかった.この 試料の断面の組織観察を行った結果, せん断力が作用 した付近で $\mathrm{TiAl}_{3}$ 相が合成されていることがわかった. もともと MA 粉末と $\mathrm{Al}$ との反応温度と $\mathrm{Al}$ の融点との 差は数十 $\mathrm{K}$ 程度しかないが, 押し出し成形では付加さ れた圧力により $\mathrm{Al}$ と MA粉末の反応温度が低下し, 部 分的な金属間化合物の合成が生じたものと推察される. 金属間化合物の生成に伴って $\mathrm{Ti}+3 \mathrm{Al} \rightarrow \mathrm{TiAl}_{3}$ の体積変 化が生じ, 成形体中には押し出し時の流線に沿ったす じ状の亀裂が発生していた.このことから, 押し出し 成形では金属間化合物の生成により半溶融状態の試料 は急速に固化したものと考えられる.

\section{4 ま と め}

MAにより Ti-5mass\%Al, Ti-10mass\%Al, Ti-32mas\%Al およびTi-64mass\%Al組成の粉末を作製し, ミリング時 間に伴う構成相の変化を調べた. また,このMA粉末 にAl粉末を添加して TiAl 組成の混合粉末を作製した. この混合粉末をパルス通電焼結により固化成形し, そ の成形メカニズムについて検討した. その結果, 以下 の結論が得られた.

(1)Ti-64mass\%Al組成の粉末は本実験条件のもとでは, $360 \mathrm{ks}$ 閒以上の MA 処理で $\mathrm{Al}$ の固溶体粉末となる.こ の粉末をパルス通電焼結により焼結すると, 焼結温度 の上昇とともに $\mathrm{Al}$ 量の多い金属間化合物相が得られ る. また, $1073 \mathrm{~K} て ゙$ 焼結すると $\mathrm{TiAl}_{3}$ を主成分とする焼 結体が得られる.

(2) MA で合成した化学量論組成より $\mathrm{Al}$ 量の少ない粉 末は, MA 時の凝集がなければ $\mathrm{Al}$ 量が多いほどアモル ファス状の粉末となる. また,これらの粉末にAl粉末 を添加して1073Kでパルス通電焼結により固化成形す ると, MA粉末中の $\mathrm{Al}$ 量が多くなるほど低温から緻密 化する. 成形時には $\mathrm{Al}$ 液相の絞り出しは観察されず, 得られた焼結体はほぼ $\mathrm{TiAl}_{3}$ 単相となる.

(3) MAで合成した化学量論組成より $\mathrm{Al}$ 量の少ない粉 末に $\mathrm{Al}$ 粉末を添加して TiAl 3 組成にし, パルス通電焼 結により 773Kにて焼結を行うと, MA 粉末と $\mathrm{Al}$ との 緻密な複合材料が得られる.この複合材料を $\mathrm{Al}$ の液相 が存在する $943 \mathrm{~K}$ で $27 \mathrm{Mpa}$ にて押し出し成形すると, せん断力が作用する部分でTiAl 3 が一部合成され，押し 出し成形は困難となる.

(4) パルス通電焼結による $\mathrm{TiAl}_{3}$ の固化成形では, $\mathrm{MA}$ 
で非化学量論組成の粉末を作製し，その粉末にAI粉末 を添加して成形した方が繳密で $\mathrm{TiAl}_{3}$ 単相からなる焼 結体を得られる.

\section{文献}

1) 辻本得蔵, 橋本健紀, 信木稔, 菅広雄: 日本金属学 会誌, 48 (1984) 435 .

2) H. Okamoto: Binary alloy phase diagram, update service, June, (1993) .

3) M.B. Winnicka and R.A. Varin : Metal. Trans. A, 24A (1993) 935.

4) 小林慶三, 西尾敏幸,三輸謙治: 粉体および粉末冶 金, 41 (1994) 536.

5）小林慶三, 西尾敏幸, 尾崎公洋, 三輪謙治: 粉体お よび粉末治金, 42 (1995) 191.
6) 小林慶三, 坂崎一茂: 粉体および粉末治金, 42 (1995) ,1247.

7) K. Miwa, K. Kobayashi and T. Nishio : Prceedings of the 3rd Intl. Conf. on semi-solid Processing of Alloys and Composites, (1994) 44-1.

8) 铇田正雄: 粉体工学会誌, 30 (1993) 790.

9）小林慶三, 杉山明, 尾崎公洋, 西尾敏幸: 粉体粉末 治金協会平成 8 年秋季大会講演概要集

10) K.B. Gerasimov and S.V. Pavlov: J. Alloys and Compounds, 242 (1996) 136.

11) T. Itsukaichi, K. Masuyama, M. Umemoto, I. Okane and J.G. Cabanas-Moreno: J. Mater. res., 8 (1993) 1817.

12) S. Srinivasan, P.B. Desch and R.B. Schwarz: Scripta Metallurgica et Materiallia ,25 (1991) 2531. 